\title{
The speaking body: Metaphor and the expression of extraordinary experience
}

\author{
JAMIE BARNES \\ University of Sussex
}

\begin{abstract}
This article explores the relationship between language, experience, and the body. Employing a phenomenological approach that takes the sensory body as its starting point, it focuses on three instances of 'divine experience', looking at the ways in which social actors seek to express that experience through metaphorical translation into more familiar, everyday realms. It argues that within this perceptual process - which starts in bodily experience and ends in words - both bodies and worlds are formed: bodies open to (often sensory) aspects of divine experience, and worlds that include the divine, alongside instances of divine agency. Indeed, such bodily conceptual and linguistic work is, social actors claim, the product of divine agency. At the heart of the three instances of divine experience explored here rests the issue of 'new birth', itself a metaphorical move employed to express a phenomenon in which the body appears to be transformed into something new, namely a habitation of divine presence. As such presence 'bubbles up' from within, it sometimes 'overflows' in words. The body speaks. Alongside exploring the metaphorical moves employed to express this type of bodily experience, this article raises the ontological question of what kind of body it is, in such cases, that is speaking, thus providing a phenomenologically inflected response to recent 'ontological' debates within anthropology.
\end{abstract}

Keywords: body; phenomenology; senses; Christian experience; metaphor; ontology; 'ontological turn'; language; being; new birth; auto-ethnography.

'And there was a guy called Mr Harrison,' Dave says, 'who was one of the older men there. He was probably about your age, about fortyish. He just said, 'God is speaking to some people in this room this morning and you just need to know that this is how you respond to him.' And he gave one or two headlines as to what to do. And I responded in accordance to what he said, really. And I felt then as though I'd got struck by lightning. These guys came running across the room, laid hands on me-young, enthusiastic guys about my own age, really. And, yeah... I just think that my life was completely radicalised within.'

'So did you feel that you got struck by lightning in your response to $\mathrm{Mr}$ 
Harrison, or when these guys laid hands on you?' I ask.

'It was as their hands landed on my head, I think.'

'Right, right. So, it was something quite... physical, as well as spiritual, you think?'

'Yeah,' Dave responds but he doesn't sound convinced, 'yeah...'

This fragment of dialogue is taken from a larger conversation between my father-in-law, Dave Webb, and me, recorded in late 2011 during a period of anthropological fieldwork. ${ }^{1}$ The purpose of the interview was to explore the story of Dave's life, with a particular focus on the events and experiences that had played a significant part in shaping him into who he is today. In this part of the conversation Dave is describing his conversion, an event which had taken place some thirty-eight years previously, in the summer of 1973. So far in the interview, Dave has described his childhood and young adulthood growing up in the north of England. He has spoken of how, from his earliest recollections, church and community life were interwoven in the lives of his extended working-class family; how, at the age of twenty-one, his curiosity about God was awakened through the seemingly miraculous transformation of the local church minister following a visit to some nearby 'revival' meetings; and, finally, he has traced his arrival at a Christian Endeavour holiday centre in North Wales where he is attending one of the early morning prayer meetings where the events described in the conversation above take place. In this meeting, as Dave responds to $\mathrm{Mr}$ Harrison's instructions - or perhaps, more precisely, as the hands of the two young men land on his head - he experiences something extraordinary. 'I felt then as though I'd got struck by lightning,' he says, expanding on his description by adding, 'I just think that my life was completely radicalised within.' Dave expresses to me, in words, a highly significant event drawn from the lived experience of his life.

1 This 18-month ethnographic fieldwork was part of an Economic and Social Research Council-funded doctoral project (grant number ES/I900934/1), based in the southern Balkans and looking at Christian experience. The research was auto-ethnographic in nature, being situated amongst the network of relationships that had emerged for me since moving to Greece as part of an 'apostolic team' in 1998 (for an in-depth account, see Barnes 2015). This interview was recorded in the lounge of our rented house in the north of Albania, in the city of Shkodër, where part of the project was based. It was later transcribed to produce the materials used here. 
The exploration of the relationship between language and experience has a long history in anthropology (e.g. Whorf 1956; Needham 1972; Classen 1993; Csordas 1990, 1994, 1997; Coleman 1996), with anthropologists interested both in how language shapes experience (e.g. Stromberg 1993, Geurts 2003) and in how experiences are shaped into language (e.g. Bruner 1986; Turner 1985). Despite this extensive work, Desjarlais and Throop (2011), in their recent review of phenomenological, experience-based approaches, highlight a lack of due attention given to adequately addressing 'linguistic, discursive, or semiotic forces' $(2011,97)$. To rectify this, they suggest future trajectories of these studies might embrace deeper explorations of the relationship between the phenomenal and the discursive, 'between, that is, experience, being, and sensate perception, on the one hand, and language, aesthetic and rhetorical forms, and communicative practices more generally on the other' (Ibid.). Similarly, Porcello, Meintjes, Ochoa and Samuels (2010), in their recent review of anthropological explorations of sensorial aspects of experience, come to the same conclusion. Although citing some notable exceptions (e.g. Classen 1993; Stoller 1997; Csordas 1994, 1997; Engelke 2007; Geurts 2003), they argue that, as with phenomenological studies more generally, 'a recurring feature in the anthropology of the senses is its rejection of language, discourse, and semiotics as modes for encountering and understanding the sensuous cultural world' $(2010,59)$.

Taking a cue from these challenges, in this article I seek to speak into the obscure space where language meets experience. As such, I employ a phenomenological approach that takes the experiencing body as its starting place (Csordas 1990; Merleau-Ponty 1962). Thomas Csordas (1990), in his seminal article on embodiment, drawing on the work of Merleau-Ponty (1962) and Hallowell (1955), directs us towards the body as the 'existential ground of culture' (Csordas 1990, 5). Whilst bringing into question a framework built around the notion of 'culture', I build on Csordas's key insight that experiences in the body form the existential ground upon which different ways of being-in-the-world are formed. Through examining my fatherin-law's and my own conversion experiences, I argue, along with Csordas, that pre-objective, deeply felt bodily sensation indeed plays a significant role in constituting one's lived world. In contrast to Csordas, however, and in large part due to my own ontological positionality in relation to the 'thatwhich-is', I feel no need to reduce such instances of divine experience to mere products of the 'socially informed body' $(1990,23)$. In this respect my work builds on recent 'ontological' challenges (Henare, Holbraad \& Wastell 2007; Alberti et al. 2011; Holbraad 2012) to take radically different domains 
of experience seriously or, in Blaser's words, to recognise 'ontologies in their own terms' (2009a, 890).

In his phenomenological work on embodiment Thomas Csordas builds on Merleau-Ponty's observation that perception starts in the body and 'ends in objects' (cited in Csordas 1990, 9), rather than the other way around. Experimenting with the implications of this line of thought, I also argue that out of pre-objective Christian conversion experiences new 'objects' (new bodies and new worlds) emerge. If the body is, as Merleau-Ponty states, a 'certain setting in relation to the world' $(1962,303)$, then the Christian body is a particular type of setting in relation to a particular type of world. As such, conversion (for the converted) is often experienced as a significant landmark event in which the body is transformed into something new and within which new spiritual sensitivities emerge, 'opening out' towards domains of divine experience that appear, previously, to have been perceptually obscured (see James 1982[1902]). It may be useful, from both an emic and an etic perspective, to speak about these spiritual sensitivities through the notion of the 'spiritual senses', as has often been done historically within the Western Christian tradition (Gavrilyuk \& Coakley 2012). However, I argue that a more fruitful approach lies in appreciating the metaphorical moves that social actors make in translating experiences from one domain into another, something that I explore in relation to my own experiences and expressions of divine experience, alongside Dave's. Finally, I put both into dialogue with articulations of divine experience recorded in the gospel stories, further showing how distinctive worlds become convincing to social actors as they compare their own experiences with these other accounts.

In relating language to experience this article explores two issues, the first linguistic, the second ontological. Firstly, what are the dynamics involved, the methods (many of them, I argue, metaphorical) by which the speaking body articulates certain aspects of its experience? And secondly, where social actors articulate aspects of what might be called 'divine experience', what kind of body is it, in such cases, that is speaking?

\section{The sensing body}

My starting point here is a phenomenological event, by which I mean the collection of experiences that Dave has described above and which acted to set his life on a new course. In this, I do not mean to say that I know exactly what happened to Dave in that early morning prayer meeting 
back in 1973. Here, I am reliant upon his description. ${ }^{2}$ But what I do mean to say is that I am willing to take seriously the fact that something very significant did happen. It was, I believe, the event itself (interwoven with Dave's subsequent descriptions of that event $)^{3}$ that changed the course of his life. Seemingly, what happened to Dave during this event was highly sensory in nature. He employs sensory terminology in order to convey his experience - he felt he got struck by lightning. At this point in the interview, I press him for further explanation. What I want to know is how embodied and concrete the experience really was; '[What you felt] was something quite... physical, as well as spiritual, you think?' What I am trying to get at is whether Dave's experience was something vague and insubstantial, two characteristics which might, I imagine, be associated with the 'spiritual', or whether it was, by contrast, something quite substantial and real, something he felt in his body.

Despite subtly rejecting my categorisation of his experience (as 'physical', as well as 'spiritual'), Dave appears to affirm the implicit notion behind my question in his subsequent description:

...yeah. I always described it as, when I was a kid, we used to collect sticklebacks in jam jars and put them on the shelf, on the window ledge outside the house. And it was great for a day or two, but then you would lose interest in them, and your mother would be saying, 'Can you clear this up.' And eventually you realise you'd better clear it up, and there was a jam jar full of dead fish and green slime. And then, as you put it under the tap outside in the garden, you put the tap on, all of this slime just came out of you, and it would sort of peel off, this green film which had attached itself to the jam jar, and you'd be left with a clean jar. I think that's what I felt happened.

As mentioned, when pressed to label his experience as 'quite... physical' Dave appears to gently resist. Why is this? Is Dave, in his momentary pause, reflecting a longstanding western dualism between the immaterial spirit and the material body (Gavrilyuk \& Coakley 2012, 3)? In other words, is he reluctant to describe what happened to him as 'physical' because God is Spirit and an encounter with Spirit should not be reduced to something 'physical'? If so, it might have been better for me to avoid any physical/spiritual categorisation altogether, and to ask if what he experienced had been something that he had felt in his body. If I had, I

2 See Stromberg (1993) for a fuller exploration of the issues surrounding this problem.

3 This being the focus of Stromberg's (1993) argument. 
strongly suspect that he would have responded affirmatively. Both his descriptions imply that what Dave experienced, he experienced in the body, his metaphors being highly evocative of deeply felt bodily sensation. As lightning might be felt as an electrifying shock or as a powerful jet of water might be felt exploding upon and cleansing an inner surface, so Dave feels the Spirit's intrusion deep within his own being. His resistance to labelling this experience as 'physical', I would therefore suggest, springs from a tacit resistance to the reduction of what kind of being he is and the elision of the ontological landscape he inhabits. For Dave, as for many other Christians, his ontology, his landscape of that-which-is extends well beyond the physical. Likewise, for Dave, as for many other Christians, the experiencing body is not merely a physical entity but is, rather, infused with and constituted by Spirit, with conversion often being experienced and conceived as the point at which this infusion takes place (Mealey 2012; Gavrilyuk \& Coakley 2012, 16; Coleman 1996).

\section{The new body: Being and perceiving}

From an anthropological perspective Simon Coleman describes how in the logic of incarnation the Christian mind and body are understood as being 'colonized by the transcendent world of the Spirit' (Coleman 1996, 111). The metaphors that a person experiencing conversion might employ are likely to be slightly different - the mind and body being 'brought to life' through the permeation of the Spirit's breath, or the experience of the Spirit as life-giving water 'bubbling up' from a deep internal spring. But the issue is the same - new birth is something to do with the Spirit emerging, settling, or dwelling within the human person. Alongside this, in what at first appears to be a paradoxical statement, Lindquist and Coleman suggest that the Christian 'believer' does not really 'believe' in the existence of God. 'For the believer,' they explain, 'the existence of God is not "believed" but "perceived"' (Lindquist \& Coleman 2008, 5, drawing on Pouillon 1982[1979]), with conversion often marking the opening up of this previously perceptually-obscured sphere. ${ }^{4}$ Through Christian conversion, therefore, a transformation occurs both in being (what one ontologically is) and in perceiving (what one is able tangibly to sense or perceive), the one being intimately interwoven with the other. The body, through the Spirit's infusion and indwelling, is transformed into something new, being also

4 Indeed, it is the startled apprehension of this previously obscured landscape that appears, in part, to so powerfully invade Dave's life during this event. 
endowed with new sensory capacities 'opening out' towards non-physical realities in new ways. ${ }^{5}$

The idea that the body's sensory apparatus might extend beyond the physical senses is not something new in Christian experience and thought (Gavrilyuk \& Coakley 2012). Origen of Alexandria, living in the second and third centuries, is credited as the first to coin the expression 'spiritual senses' (sensus spiritales) to refer to those parts of the sensorium that extend beyond purely physical human perception (Ibid., 2-4; Vinge 1975 cited in Howes $2009,18)$. Augustine, two centuries later, believed that it was through such spiritual senses that 'God and God's activity in the world' could be discerned (Lootens 2012, 56). And in the 1700s John Wesley specifically associated conversion with an 'opening of the spiritual senses' by which the divine began to be perceived (cited in Mealey 2012, 253). Aristotle, Classen tells us $(1993,2)$, numbered the senses as five. Many early Christian authors in the West, following Aristotle, developed their notions of the spiritual senses around an idea of there being five spiritual senses which worked in a way 'analogous to but not reducible to ordinary sense perception' (Gavrilyuk \& Coakley 2012, 3). Thus, Augustine wrote of how he 'tasted' God and was 'touched' by him, found him 'fragrant', and spoke of how God 'shattered [his] deafness' and 'put to flight [his] blindness' (from his Confessions, cited in Gavrilyuk \& Coakley 2012, 3).

However, much contemporary anthropological work on the senses problematises local assumptions about the numbering and ordering of the senses. Kathryn Geurts convincingly argues that the commonly held EuroAmerican notion of there being five senses is itself merely a historically, socially, and culturally constructed 'folk ideology' $(2003,7)$. She points out that if, in accordance with contemporary scientific logic, the qualification for something being categorised as a sense is that it possesses a corresponding physical 'organ' (e.g. the ear for hearing, the nose for smelling, the skin for touching etc.) then balance, which has such a corresponding 'organ' (the vestibular organ of the inner ear), should also be labelled as a sense (Ibid., 4). Not stopping at balance, late twentieth century sensory scientists, Geurts tells us, 'would probably agree on a taxonomy of approximately nine sensory systems' (Ibid., 8). David Howes, quoting Durie, points out that the more materialist scientists 'study the structure of our sense organs,

5 Within this ontology of the body, materiality and immateriality, as categories to think with, slide into the background. If materiality is understood as that which reveals itself to the senses (Tilley 2004), that which can be sensed, then the Spirit, in these terms and to the body described here, is also material. 
the more senses we appear to have' (Durie 2005, 35 cited in Howes 2009, 23), conservative estimates putting the number at ten, more radical ones estimating it as high as thirty-three (Ibid.).

If contemporary neuroscience unsettles commonly held assumptions about the sensorium, cross-cultural explorations of sensory orders further reveal the contingent nature of our own understandings. The 'anthropology of the senses' (e.g. Classen 1993; Classen \& Howes 1996; Classen 1999; Howes 2009; Classen, Howes \& Synnott 1994) has, in large part, done this through showing how different people in different places and at different times number and order the senses in a vast variety of different ways. One thing that emerges from this body of work is that local sensory orders reflect indigenous 'ethno-ontologies', local experiences and understandings of what exists and is valued in the world that might be sensed (see Geurts 2003). In thinking about Christian experience this is where the notion of the 'spiritual senses' finds, at least from an emic perspective, its ontological appeal. It locates in the body (even if we leave open our understandings of what the body actually is) senses capable of perceiving aspects of reality beyond those apprehended through more narrowly constructed sensoriums. In appealing to the senses a Christian implies two things, both ontological and each reflecting the other. The first concerns the nature of the world that he or she inhabits, and the second concerns what kind of being he or she is inhabiting that world. If perception, as Merleau-Ponty has argued, starts in the body and ends in objects (cited in Csordas 1990, 9) or 'things', the Christian puts his or her particular mark on the world by proclaiming that what he or she has sensed in the body is God, and in so doing constructs not only the world perceived but also the body that perceives it. In other words, the Christian's inhabited world and body (like every other inhabited world and body) emerge out of perception.

\section{Speaking}

'[T] he goal of a phenomenological anthropology of perception,' Csordas writes $(1990,9)$, 'is to capture that moment of transcendence in which perception begins, and, in the midst of arbitrariness and indeterminacy, constitutes and is constituted by culture.' Dave's lightning experience seems just one such transcendent moment, a vivid experience, a moment of 'existential beginnings' in Csordas's terms, something he experienced, quite powerfully I have suggested, in his body. But what exactly does Csordas mean here by 'culture'? Elsewhere he speaks of the 'socially informed body' 
(1990, 23), locating this as the site through which perception emerges. The idea, of course, is that the body is located and embedded and has a locally constituted habitus through which experience in the body is reflectively objectified. By inference, the words 'social' and 'culture' highlight the role of human others in this process, something which may, in fact, obscure other formative dynamics within perceptual processes. As such, I would suggest a slightly broader reading. Alongside 'culture', I would suggest that a being's perception is constituted by its experience-thus-far-of-life-inthe-world, including the vast array of material environments within which it has grown and been grown and that have played their part in shaping its 'perceptual orientation' (Ingold 2000a, 144).

At the point that Dave is 'struck by lightning' and takes it to be God, he reveals at least two aspects of his experience-thus-far-of-life-in-the-world, namely, that he knows what lightning is and can at least imagine what it feels like to be struck by it (either through experiences of his own or through relating to the experiences of others); and secondly, that he has an (also undoubtedly socially constituted) conception of a being called 'God'. However, what is of note here is that, in seeking to express his experience (Bruner 1986; Dilthey 1976), Dave makes no appeal to any language of the 'spiritual senses'. Nor does Augustine, as the statement quoted above demonstrates. Both simply employ the language of the common senses, and leave implicit the fact that when, for instance, Augustine speaks of 'tasting' God, he is not referring to the stimulation of taste buds within his mouth. Likewise, Dave told me he felt as if he had been struck by lightning, leaving the interpretation of what he meant by that to me. And this brings us to an interesting point. The notion of the 'spiritual senses', although appealing in that, by extending a corporeal sensorium, it appears to give us a framework and language to talk about aspects of divine experience not easily conceptualised through more narrow conceptions, nonetheless remains, within Western thought, closely linked to a fivefold sensory model.

As we have seen through the work of Geurts and others, reifying this fivefold model as ontologically pre-existent is itself problematic, because sensoriums vary from place to place. This in itself should make us extremely cautious about reifying an extended tenfold model based on five 'corporeal senses' and five 'spiritual' ones, a point to which Christian thinkers have themselves been sensitive. Recognising no tangible 'spiritual sense organs' comparable to the more visible 'corporeal sense organs' has, for many, brought the strict delineation of five spiritual senses into question (LaNave 2012, 165; Rahner cited in Gavrilyuk \& Coakley 2012, 5). Origen himself 
spoke of 'one divine sense', but went on to speak of the 'many forms of that sense' (McInroy 2012, 25, my italics). Karl Rahner, in a seminal article written in the 1930s, at first expounded a doctrine of the spiritual senses closely analogous to five physical senses, but in his later work considered such a strict division 'rather forced', preferring instead to emphasise 'the unitive character of spiritual perception' (Gavrilyuk \& Coakley 2012, 4f.). What, then, is happening when Christians, such as Dave or Augustine, employ sensory language in order to express their experiences of the divine?

To answer this question, we might come back to the 'goal' of a phenomenological anthropology of perception (Csordas 1990, 9). If the moment of transcendence is that point of 'existential beginnings', the point where what is experienced in the body meets a being's relationally constituted experience thus far of its life-in-the-world, then perception is what emerges from that place. In relational (cultural) contexts that emphasise five senses, Geurts argues $(2003,56)$, subjective human experience and perceptual events become categorised, formed, in terms of those five sensory channels, the acquisition of language aiding in this objectifying process (Ibid.). The implication is, of course, that in contexts where different sensory models exist, subjective human experience would be formed and expressed differently, something that Geurts illustrates through her work with the Anlo-Ewe speaking people of West Africa. For the Anlo-Ewe, for whom indigenous bodily understandings reflect ways of being-in-the-world very different from those common in many Euro-American contexts, subjective human experience ('feeling in the body') is, needless to say, conceptualised and expressed without any reference to a fivefold model (Ibid., 41).

With this in mind we may return to Augustine's description of tasting, touching, smelling, hearing, and seeing God with an understanding that moves us away from the danger of reifying our notion of the 'spiritual senses', yet at the same time allows for an emic perspective of the body and the world in which the divine exists and might be tangibly sensed. If Augustine spoke of 'tasting' God and yet was not referring to something that happens in the mouth, we must assume that he was referring to something else. We might suggest that, living within the paradigm of a fivefold sensorium, he was merely expressing his subjective experience of the divine, what he perhaps even experienced in the body, ${ }^{6}$ within the conceptual sensorial terms

6 I say what he 'perhaps... experienced in the body' because it is, of course, possible that Augustine is translating experience from a domain other than bodily sensation or sensory perception. He may, it is conceivable, be speaking, for example, not so much about perception as about desire. 
that were available to him, in other words the language of the five senses. At heart, he was translating experience from one domain (his experience of God) to another domain (his experience of the senses). He was, in other words, making a fundamentally metaphorical move.

\section{Translating experience \& experiencing bodies}

Lakoff and Johnson (2000[1980]) argue that metaphor - the capacity to understand and experience one kind of thing in terms of another - is central to the ways in which we organise our lives. Our conceptual systems, which govern our thoughts, actions, and perceptions, are fundamentally metaphorical in nature. For the anthropologist James Fernandez (1972), metaphor works by connecting two distinct domains of experience, a process that often involves relating inchoate experiences to more concrete, observable realms. 'Thus,' writes Fernandez $(1974,122)$, 'in "mercy... droppeth as the gentle rain from heaven," the "gentle rain" gives to the abstract and vaguely conceived "mercy" a concreteness that literal definition is hopeless to achieve.' It is important to note here that, from a phenomenological perspective, metaphor does not devalue certain spheres of experience as being less 'real' than others. ${ }^{7}$ It simply moves or translates one domain into another, often tentatively and experimentally, due to the essential untranslatability of phenomena. Building from the materials of experience, we imaginatively play with different metaphors, trying and testing their effectiveness to express different aspects of that experience, as well as their capacity to situate us in particular and desired ways in the world (Kirmayer 1993, 185, 187).

With this in mind I wish to move from a consideration of Dave's experience to a consideration of my own experience. Since within anthropology the embodied ethnographer is him or herself 'the research instrument par excellence' (Hammersley \& Atkinson 2007, 17), a reflexive exploration of one's own experience and ontological positionality seems an ethical necessity when considering the experience and ontological positionality of others, as these aspects inevitably, and often tacitly, influence and shape one's interpretation of the 'other's' world (Ewing 1994). The importance of bringing

7 For example, to the person experiencing mercy, caught in a trap, embroiled in relationships of unequal power and feeling the weight of life-circumstances bearing down upon them, the easing, removal or complete dissolution of that weight by an agentive hand (i.e. 'mercy') no doubt constitutes a very real existential phenomenon. It is this phenomenon, this domain of experience, that the subject seeks to express through making a metaphorical appeal to a different domain (in this case the dropping of 'gentle rain from heaven'). 
my own experience into dialogue with that of other research participants became clear to me whilst carrying out the doctoral research on which this article is based. Since the object of my research was Christian experience, and my specific focus was the group of which I had been part for many years, the question was not whether I should include my own experience in the study, but why I would even consider excluding it, especially in light of the fact that reflexive and auto-ethnographic practices have a long-established history in anthropology (Okely \& Callaway 1992), including many autoethnographic accounts of what might be called 'extraordinary' encounters (e.g. Stoller \& Olkes 1987; Favret-Saada 1980; Turner 1992). Hence, in 2013, I embarked on writing an auto-ethnographic account of my own conversion experience, something which had taken place many years earlier, in Cambridge in early 1995. The following passage is taken from that account:

...on the first day of the mission, having initially been quite resistant to attending the meeting, my 'heart' changed throughout the day so that, by the early evening, I felt a kind of internal, gently bubbling excitement about going, actually a kind of joy. Upon entering the auditorium, my friend and I found a place to sit... When the speaker began to talk, I began to listen in a way in which I had never listened before. In truth, I found him very easy to listen to; he spoke in a calm and mildly humorous way. But my attentiveness cannot merely be explained by his agreeable style. Most remarkable to me was how much I wanted to listen, how much I wanted to understand the things he was talking about. My listening, I found, was centred in a very deep part of my body, in a very deep part of my being. My attention was 'gripped' in a gentle but firm way. Alongside this, there was a feeling of opening out, a kind of inner spaciousness that connected me with the spaciousness around me. I felt both 'gripped' and, at the same time, totally at ease. It was as if the very spaciousness in which I found myself was enabling my attention to be focused. As this man spoke, it seemed to be bringing not only a change in my understanding, of my possible 'place' within a new and different story, but also a change in how I was experiencing listening itself. Metaphorically, if the body were compared to a house, it felt like underground rooms that had been shut up and never used before were being opened up, and with that came the opening of a different realm of sensory awareness, a different capacity to hear. (Barnes 2015, 74f.)

What I am describing here, from the 'gently bubbling excitement' to the feeling of 'inner spaciousness' and 'opening out', to the sense of attentiveness 
in 'a very deep part of my body', is brought together in my final metaphor of the house. In 'translating abstract bodily feelings into words' (Hunt \& Sampson 2006, 21), I am moving experience from one sphere (deeply felt bodily sensation) to another sphere (the image of the underground rooms of a house being opened up). The interesting connection between this experience and Dave's is the appeal that both make to things felt inside the body, to sensations within some kind of inner space. With Dave, this comes across most strongly in the second metaphor he employs, his description of the forgotten jam jar, 'full of dead fish and green slime'. The key moment, of course, is when the jam jar is put under the tap, the tap is turned on, and 'all of this slime just came out of you, and it would sort of peel off, this green film which had attached itself to the jam jar, and you'd be left with a clean jar'. What appears like a verbal slip - 'all of this slime just came out of you' - in fact simply highlights the way in which the metaphor is working. Dave is connecting different domains of experience in order to convey what he felt. Whatever 'hit' Dave that morning was something like a powerful jet of fresh water (and something like lightning) which somehow went right inside him and peeled off a layer of internal 'slime'. My experience, although more gentle and therefore appealing to a different metaphor (underground rooms opening up and letting in both light and air), points to a similar shift in internal bodily sensation.

From a phenomenological perspective, Tim Ingold (2000b) argues that it is only in the appeal that metaphor makes to a shared familiarity of sensory experience that it finds its resonance or power. He illustrates this through describing what it felt like for him to stand next to a railway crossing just at the point that a train raced past. 'It thundered past me,' he writes, 'in a flash.' To convey something of his experience, Ingold connects several different sensory domains - the sound, sight, and feel of the train racing past, with the sound and feel of thunder, and the shocked visual sensation of lightning. The aptness of this metaphor to convey such a highly sensory experience, he argues, depends upon a shared familiarity between the speaker and his audience of the sound of thunder and the sight of lightning. In knowing these, the listener (or reader in this case) can sense something of the speaker's (or writer's) experience, even if that same person has never stood by a railway track and experienced a train racing past. Ingold is careful to point out that what he is speaking about here is more than just a conceptual familiarity. It is, rather, a familiarity rooted in personal experience. ' $[\mathrm{I}] \mathrm{n}$ having recourse to this metaphor,' Ingold states, 'it is my experience that I want to convey to you, not some conceptual prototype of a "passing train" for which the audi- 
tory and visual sensations of thunder and lightning happen to provide apt vehicles of symbolic expression.' (Ibid., 285) It is, he argues, in connecting different domains of experience that people continually forge and re-forge the verbal conventions of their society in efforts to make themselves, and their own sensory practices and experiences, understood to others (Ibid.).

Dave, in seeking to convey to me his very real, very tangible experience, engages in exactly this kind of metaphorical work. The two primary metaphors he employs - being struck by lightning and the cleaning out of the dirty jam jar - both appeal to an assumed shared familiarity, rightly in this case, between him and me of these two different domains of experience. I am familiar both with experiencing lightning (although, admittedly, not being struck by it) and with the green films of slime that collect on the inside of neglected jars. At the same time, these metaphors work, they resonate with me, his audience, because of a shared understanding, rooted also in my personal experience, of human bodies and the worlds they inhabit. In my understanding God is the kind of being that, were one to encounter, could certainly engender a feeling in the body similar to being struck by lightning. And in my own experience, although for the most part worked out in gentler ways than the experience Dave describes, the Spirit does intrude deep within one's own being, bringing about a radical change. In this way Dave's metaphors make sense to me, his audience, because they appeal to a shared familiarity of bodily experience alongside similar conceptual understandings and interpretations of that same sensory experience.

\section{Speaking bodies}

Stories about Jesus present him as a master of metaphor, continually, in Fernandez's terms, connecting his experience of the inchoate ('heaven') to the more concrete ('earth'), whilst simultaneously being misunderstood by those around him who believe him to be speaking in purely literal terms (i.e. with no translation between different spheres). Thus, when Jesus tells Nicodemus that he must be 'born again', the latter makes no metaphorical translation, and understands Jesus to be talking about a literal re-birth. ${ }^{8}$ How can an old man enter a second time into his mother's womb?' Nicodemus asks incredulously. Similarly, when Jesus meets the Samaritan woman at the well, ${ }^{9}$ he begins to talk to her, through metaphorical translation, about

8 The story is found in John, chapter 3.

9 The story is found in John, chapter 4. 
aspects of divine experience which she, throughout the conversation, continues to understand in literal terms (i.e. devoid of any translational movement). Jesus offers her 'living water'. She misunderstands, believing him to be talking about the physical water in the well. 'You have nothing to draw with, and the well is deep,' she says. 'How are you hoping to get this "living" water?'

What is pertinent here in terms of my argument thus far is that Jesus is using the concrete, physical environment around him to speak about more inchoate aspects of divine experience centred in the human body. 'Everyone who drinks this (physical) water will thirst again,' he says, 'but the water that I give a person will not only quench all thirst, but will become within that person a well of water springing up to eternal life.' The woman - whether deliberately or not - continues to ignore the metaphorical movement and to misplace the subject of Jesus's utterance in the external environment, causing Jesus in response to address her 'heart', that centre of charismatic devotion attached, at present, to a charismatic object - a 'well' - that promises much, but is failing to deliver to her the waters of Life (see Barnes 2015; Shils 1975; Csordas 1997, 138; Eisenstadt 1968, $x x v i)$. Jesus, in exposing her attachment to an untrustworthy charismatic object, is no doubt prompting her to recognise him as the Christ, a worthy charismatic 'object', or leader, able to open deep within her own being a genuine spring of living water. There is a very real sense in which Jesus, through these metaphorical moves, is speaking about the body, through the Spirit's infusion, becoming something new.

If we return to Dave's and my experiences, we can see these same themes of internal transformation emerging. Dave describes himself as being 'completely radicalised within' and, through his employment of the image of fresh water peeling off an inner layer of slime, expresses that this experience was deeply cleansing, perhaps cleansing of an inner part of him that few other experiences had ever reached. I describe a gently bubbling excitement, developing into a deep listening, opening out to an inner spaciousness, which in sum felt like a very deep part of me opening up and letting in fresh, clean air. In both cases there is a change within, the very thing that Jesus points to through his metaphor about the opening up of a deep, internal living spring. And here we can see why Christians like Dave and I might find such stories about Jesus so convincing and how they might easily become authoritative guides as to how the world is. In this story of encounter with a Samaritan woman, and others like it, Jesus seems to point to an experience of the body and the world that, in resonating with one's 
own experience of the body and the world, appears to remarkably shrink, if not collapse, the distance between one's own lived world and his. ${ }^{10}$

Expressions of such 'changes within' are common within the literature dealing with Christian conversion, with metaphors of 'depth', the 'heart', the 'Spirit', and the 'soul' often being employed to express such experiences (see de Witte 2011; Harding 2000, 19, 34; Stromberg 1981; Turner \& Turner 1978, 8; Lootens 2012, 56, 64). For example, William James (1982[1902]), in his seminal work on religious experience, amidst a host of similar examples, records the following case:

I remember the night, and almost the very spot on the hill-top, where my soul opened out, as it were, into the Infinite, and there was a rushing together of the two worlds, the inner and the outer. It was deep calling unto deep - the deep that my own struggle had opened up within being answered by the unfathomable deep without, reaching beyond the stars. $(1982,66$.)

Other instances recorded by James speak of a 'stirring of the heart' (Ibid., 67); the 'heart bound[ing] in recognition' at God's voice (Ibid., 69); an 'explosion' of joy in 'the bottom of my soul' (Ibid., 225); and something happening 'in my interior mind', whose 'impressions, more rapid than thought, shook my soul' (Ibid., 226). James relates such experiences to a level of deep, sensed intuitions and impulses that fall beneath the level of everyday consciousness. Indeed, writing at the dawn of the twentieth century, he applauds the then recent steps in psychology acknowledging a level of sub-conscious awareness falling outside what he calls the 'ordinary field' (Ibid., 233), suggesting that this 'deep' sphere of human experience might well be the very place that 'if there be higher spiritual agencies that can directly touch us, the psychological condition of there doing so might be our possession of a subconscious region which alone should yield access to them' (Ibid., 242 , italics in original).

The relationship between 'inner' experiences and being 'touched' by God has been dealt with more recently by Marleen de Witte (2011) in her research carried out in a Ghanaian charismatic church. As with the cases above, de Witte also records expressions of experience formed around metaphors of 'inner depth'. One church member tells de Witte, 'You have to open your heart to the Spirit... when the Spirit touches you, you feel it deep deep in-

10 The reason, I would suggest, that neither Nicodemus nor the Samaritan woman initially understood Jesus's metaphorical translations may well have been because there was no resonance between Jesus's experience of his body and the world, and their own. 
side' $(2011,491)$. Such 'inner' experiences authenticate, de Witte suggests, a particular religious subjectivity (Ibid., 492), but can also be connected to the wider social and structural context within which such experiences take place (Bourdieu 1990[1980]). Drawing on Meyer's notion of 'sensational forms' (2010) alongside work on the disciplining of the senses and the body (e.g. Chidester 1992, 2005; Csordas 1997), de Witte is able to account for these experiences as being generated by a powerful and complex interplay of charismatic performance and 'encoded, learned bodily behaviour' (de Witte 2011, 491). Although appearing immediate and spontaneous, 'the feeling of the Holy Spirit touching,' de Witte argues, 'is produced by adopting and repeatedly practising certain bodily forms' (Ibid., 505). As such, De Witte's work raises the question of authenticity. If church members' experiences can be accounted for through the disciplining of the body and the tuning of the senses within a particular charismatic regime, then can any of these experiences be attributed to a genuine encounter with a divine being?

In a sense de Witte leaves this question unanswered, or perhaps, even, unasked. The theoretical framework she sets up is, indeed, particularly convincing when applied to what William James might call 'excited assemblies' where 'suggestion and imitation', as James $(1982,229)$ puts it in a far less theoretically developed way, undoubtedly play a significant role in engendering experience. ${ }^{11}$ And yet, because it is convincing, this same framework obscures the aspect that, for me, is the most interesting - human beings' actual engagement and interaction with the divine. Since everything may be accounted for through a process of learned embodiment, God - as an actual living being - appears strangely absent from the Ghanaian church setting that de Witte describes. Is this actually the case? Or is this merely the impression created by the analytic frame through which we are invited to perceive this other world?

Following Merleau-Ponty's idea that perception starts in the body and ends in objects, I have suggested that people put their particular ontologi-

11 De Witte deals with more 'excited' and less 'excited' assemblies in this article, using the same theoretical framework. However, the framework would seem less powerful in explaining certain unpremeditated experiences such as, for example, that of President Finney, recorded by James (1982, 255): '[A]s I turned and was about to take a seat by the fire, I received a mighty baptism of the Holy Ghost. Without any expectation of it, without ever having the thought in my mind that there was any such thing for me, without any recollection that I had ever heard the thing mentioned by any person in the world, the Holy Spirit descended upon me in a manner that seemed to go through me, body and soul. I could feel the impression, like a wave of electricity, going through and through me. Indeed, it seemed to come in waves and waves of liquid love; for I could not express it in any other way. It seemed like the very breath of God. I can recollect distinctly that it seemed to fan me, like immense wings.' 
cal mark upon the world by interpreting bodily sensations in particular ways (something as true for anthropologists as for anyone else). As such, metaphorical translation of experience from one domain to another is by no means a neutral process, but is also a rhetorical, agentive construction of the world as one imagines, hopes, and wishes it to be. Following this, it stands to reason that Dave could have explained what happened to him in that morning prayer meeting in completely different terms from the way he did, or could even now re-interpret his experience, thus producing different 'objects' and a different 'world' in which to live. When Dave arrived at the prayer meeting he was, in fact, feeling 'physically sick' and 'exhausted' from a series of late nights and early starts. At the same time, he arrived with a sense of expectation, even urgency about what might happen:

I had this sense of, 'Oh dear me, this is the last day of the week.' I was actually on holiday for two weeks, and this was the end of the first week. And I think I just had this sense within me that something was going to happen today. And I went in, and literally within minutes of sitting down I felt God speak to me.

'In what way?' I ask.

Well, through tongues and interpretation of tongues - which was not spoken, 'David Webb, blah, blah, blah.' It was spoken out into the meeting. And for the next hour I sat there sweating my pants off really, because I didn't really know quite what to do, or how to respond. But I knew that in some way I needed to. And so, round about an hour later, coming up to eight o'clock, if I'm not mistaken, there was another sort of prophetic type word. And at that point, I knew that I needed to respond. And there was a guy called Mr Harrison, who was one of the older men there...

Here we see what happened in the run up to Dave's 'lightning' experience. It is not difficult to draw out from this an embodied psychological drama that explains his experience without requiring any reference to God as a living agent. Dave arrives somewhat disorientated (tired, feeling physically sick etc.) and, at the same time, with a pressing sense of urgent anticipation (his time at the camp is running out). He is 'open' to something happening, and seems to be almost willing it. It is within this context that something does happen (a 'word' spoken out into the meeting) that Dave interprets as God speaking to him. In Merleau-Ponty's terms, perception (hearing the voice of another person) ends in an object (God). It seems also that the voice, whatever it said, has invited a response that sets Dave on edge ('sweating 
[his] pants off') for the next hour. The tension increases. Another person speaks. One of the older, authority figures in the room affirms that God is speaking, further concretising God as an object present in the gathering. Dave responds to this man's instructions, the two young guys come running across, lay hands on him, and (bang!) lightning. Dave, through his own expectations and the charged social environment in which he found himself, was 'set up' for just such an embodied experience. His 'encounter' can be explained in these terms.

But this, of course, is not Dave's explanation of these events, nor for that matter my own. As stated, the Christian subject puts his or her particular mark on the world by proclaiming that what he or she has sensed in the body is God, and in so doing constructs not only the world perceived but also the body that perceives it. And this brings us back to a crucial point. The body, as we have seen, speaks. But what kind of body is it that is speaking? From an etic perspective, Christian conversions such as Dave's or mine, have often been explained in terms apart from any ontological transformation within the body itself. Therefore, Stromberg (1993) points to the reconciliation of psychological anomalies through conversion narratives; Harding (2000) attributes conversion in large part to a shift in language; and even Csordas $(1990,23)$ explains aspects of divine experience as the product of the 'socially informed body' rather than the product of any subjective experience of God. An emic perspective, on the other hand, explains the conversion experience as an 'encounter', a meeting with a divine Being that results in the ontological transformation of the body itself, the opening up of an internal 'spring' (the Spirit) that was simply not open before that moment in quite the same way. The body, essentially, is transformed into something new. And it is this body, the body that is open to domains of divine experience, that speaks, often employing metaphor to translate that experience into more familiar realms.

\section{Conclusion}

More than a hundred years ago William James took up this same issue of the new body in his work on, for the most part Christian, conversion. He thought it was 'natural' that those experiencing the kind of phenomena I have explored here could well come away feeling that they had been worked on by a higher power, warranting their subjective belief 'in a radically new substantial nature' $(1982,228)$. Drawing on the cases available to him, James identified several repeated themes within this transition, one of 
which was 'an objective change which the world often appears to undergo' (Ibid., 248). As I have shown in this article, on the one hand this change relates to ontology or being, as exemplified in the words James quotes from Joseph Alleine, the New England Puritan: 'the sincere Christian is quite a new fabric, from the foundation to the top-stone. He is a new man, a new creature' (Ibid., 228). On the other, it relates to perceiving, as exemplified in the words of Jonathan Edwards, the revivalist preacher: '... it follows that... there are [also] new perceptions and sensations entirely different in their nature and kind from anything experienced by the [same] saints before they were sanctified' (quoted in Ibid., 229).

The issue of radically different natures has surfaced more recently in anthropological thought through a growing body of work associated with what has come to be known as the 'ontological turn', which argues that ontologies, worlds, and natures give us better tools to think with than the previously popular anthropological concept of 'culture' (Holbraad et al. 2010). In this vein Mario Blaser argues that the employment of the culture concept is the product of a particular trajectory of modernity that obscures or denies radical difference through a process of what he calls 'Sameing' (Blaser 2013, 549; see also Blaser 2009a, 2009b; Descola 2013). This process works, Blaser explains, because the ontology of modernity, and of Euro-modernity in particular, is built on a fundamental distinction between Culture (a realm of human creation) and Nature (a realm of existing things), within which the concept of culture tames radically different worlds by explaining their difference as merely 'cultural perspectives' upon a single, pre-existent reality. ${ }^{12}$ In place of 'culture', the 'ontologists' (Bessire \& Bond 2014) propose tackling the differences usually apprehended as cultural in a more radical way, in other words in terms of ontologies being played out amongst, at times, incommensurable worlds (Blaser 2013, 565; Holbraad 2012).

My approach here, in taking up Csordas's theory of the body as the 'existential ground' not just of 'culture' but of ontology, has been to seek to embed ontology in experience and, in so doing, to show how both bodies and worlds emerge out of perception. Through a focus on philosophical and conceptual solutions to alterity, to quite literally thinking through things (Henare, Holbraad \& Wastell 2007), one of the weaknesses of ontological approaches thus far has been their avoidance of considering the role that phenomenological aspects of experience play in the perception, perfor-

12 'There is,' Vigh and Sausdal (2014) explain, 'in the ontological turn, not one nature (human) and many cultures (people), but many worlds of separate and incommensurable ontologies, or "multiple natures", as Viveiros de Castro terms it.' (See Viveiros de Castro 1998; 2011; 2015) 
mance, and constitution of various worlds (Mitchell 2015). In employing a phenomenological method, I have sought to highlight an embodied, experiential, and subjective approach to ontology that explores the ways in which different embodied knowledges and worlds come into being. If perception starts in the body and ends in objects, this is certainly not to say that there are no 'things' out there in the world to sense, but it is rather to highlight the way in which different lived worlds emerge through the perceptual process.

In line with what William James observed, for both Dave and me our conversions marked distinctive turning points in our lives when certain modes of perception came alive to us. Two years after my interview with Dave, and when I was writing about and reflecting upon my own conversion experience, I raised this point with him in conversation. Did he feel (as I did) that the way he experienced his body before and after his conversion was somehow different? He responded by saying that he had no doubt that this was the case. We might attribute this to a process of socialisation, a learning of a charismatic habitus or encoded bodily behaviour that both engenders experience and teaches a person how to read bodily sensations in particular ways, and through this bring God, as an object, into one's landscape of that-which-is (Csordas 1990; de Witte 2011; Luhrmann 2012). However, for many of us such explanations are insufficient. They fail to resonate with what we understand the world to contain, nor do they take full account of experiences that, when they took place, surprised us because they were unpremeditated, unusual, or out-of-place: experiences which happened, in President Finney's words, '[w]ithout any expectation... without ever having the thought in [our] mind[s] that there was any such thing.' (Quoted in James 1982, 255.)

Each time the body speaks it makes its world anew. Caught on the cusp between past experience, its experience-thus-far-of-life-in-the-world, and a nascent world in large part brought into being by the body's own articulations, the speaking body negotiates a path that it also bears responsibility for forming. In so doing, worlds are created, objects are formed in MerleauPonty's terms. Included within this process of objectification is the body that is speaking. If, as social actors seem to claim, the body is transformed into something new through conversion-type experiences such as the ones explored here, this raises the question of how we might conceptualise such ontological transformations. Social actors, as I hope to have shown, develop their own solutions to this problem. In seeking to conceptualise and articulate their experiences they often metaphorically translate them into different spheres, a process that reveals assumptions both about the world 
(for example the 'things' it contains) and the body (for example its sensory 'capacities') that inhabits it. In this light one of the metaphorical themes that emerges in the examples addressed here is that of divine experiences as they relate to notions of existential 'depth'. This raises questions for further investigation: not only the question of the significance and role of phenomenologically 'deep' experiences in shifting an individual's ontology, but also the question of whether the body occupying such spheres of divine experience is experientially and ontologically different from other types of experiencing bodies, and, if so, in what ways?

JAMIE BARNES is Teaching Fellow of Sociology with Special Reference to the Study of Religion at the University of Sussex. E-mail: jb368@sussex.ac.uk

Bibliography

Alberti, Benjamin \& Severin Fowles \& Martin Holbraad \& Yvonne Marshall, \& Christopher Witmore

2011 Worlds Otherwise: Archaeology, Anthropology, and Ontological Difference. - Current Anthropology 52(6), 896-912.

Barnes, Jamie

2015 'Stories, Senses and the Charismatic Relation': A Reflexive Exploration of Christian Experience. - PhD Dissertation. University of Sussex.

\section{Bessire, Lucas \& David Bond}

2014 Ontological Anthropology and the Deferral of Critique. - American Ethnologist 41(3), 440-56.

\section{Bialecki, Jon}

2014 Does God Exist in Methodological Atheism? On Tanya Lurhmann's 'When God Talks Back' and Bruno Latour. - Anthropology of Consciousness 25(1), 32-52.

\section{Blaser, Mario}

2009a Political Ontology: Cultural Studies without 'Cultures'? - Cultural Studies 23(5-6), 873-96.

2009b The Threat of the Yrmo: The Political Ontology of a Sustainable Hunting Program. - American Anthropologist 111(1), 10-20.

2013 Ontological Conflicts and the Stories of Peoples in spite of Europe. Current Anthropology 54(5), 547-68. 


\section{Bourdieu, Pierre}

1990[1980] The Logic of Practice. Translated from Le Sens Pratique by Richard Nice. Stanford: Stanford University Press.

\section{Bruner, Edward}

1986 Experience and its Expressions. - Turner, Victor \& Edward Bruner (eds), The Anthropology of Experience, 3-30. Urbana: University of Illinois Press.

\section{Chidester, David}

1992 Word and Light: Seeing, Hearing and Religious Discourse. Urbana, IL: University of Illinois Press.

2005 The American Touch. Tactile Imagery in American Religion and Politics. - Constance Classen (ed.), The Book of Touch, 49-65. Oxford: Berg Publishers.

\section{Classen, Constance}

1993 Worlds of Sense: Exploring the Senses in History and across Cultures. London: Routledge.

1999 Other Ways to Wisdom: Learning Through the Senses across Cultures. - International Review of Education 45(3-4), 269-80.

\section{Classen, Constance \& David Howes}

1996 Making Sense of Culture: Anthropology as a Sensual Experience. Etnofoor 9(2), 86-96.

\section{Classen, Constance \& David Howes \& Anthony Synnott}

1994 Aroma: The Cultural History of Smell. New York: Routledge.

\section{Coleman, Simon}

1996 Words as Things. - Journal of Material Culture 1(1), 107-28.

\section{Csordas, Thomas}

1990 Embodiment as a Paradigm for Anthropology. - Ethos 18(1), 5-47.

1994 Embodiment and Experience: The Existential Ground of Culture and Self. Cambridge: Cambridge University Press.

1997 Language, Charisma, and Creativity: The Ritual Life of a Religious Movement. Berkeley: University of California Press.

\section{De Witte, Marleen}

2011 Touched by the Spirit: Converting the Senses in a Ghanaian Charismatic Church. - Ethnos 76(4), 489-509.

\section{Descola, Philippe}

2013 Beyond Nature and Culture. Chicago: University of Chicago Press.

\section{Desjarlais, Robert \& Jason Throop}

2011 Phenomenological Approaches in Anthropology. - Annual Review of Anthropology 40, 87-102. 


\section{Dilthey, Wilhelm}

1976 Dilthey: Selected Writings Edited and Introduced by H.P. Rickman. Cambridge: Cambridge University Press.

\section{Durie, Bruce}

2005 Doors of Perception. - New Scientist 185(2484), 34-6.

\section{Eisenstadt, Shmuel}

1968 Introduction. - Weber, Max \& Shmuel Eisenstadt (ed.) Max Weber on Charisma and Institution Building: Selected Papers, ix-lvi. Chicago: University of Chicago Press.

\section{Engelke, Matthew}

2007 A Problem of Presence: Beyond Scripture in an African church. Berkeley: University of California Press.

\section{Ewing, Katherine}

1994 Dreams from a Saint: Anthropological Atheism and the Temptation to Believe. - American Anthropologist 96(3), 571-83.

\section{Favret-Saada, Jeanne}

1980 Deadly Words: Witchcraft in the Bocage. Cullen, Catherine (trans.). Cambridge: Cambridge University Press.

\section{Fernandez, James}

1972 Persuasions and Performances: Of the Beast in Every Body... and the Metaphors of Everyman. - Daedalus 101(1), 39-60.

1974 The Mission of Metaphor in Expressive Culture [and Comments and Reply]. - Current Anthropology 15(2), 119-45.

\section{Gavrilyuk, Paul \& Sarah Coakley}

2012 Introduction. - Gavrilyuk, Paul, \& Sarah Coakley (eds), The Spiritual Senses: Perceiving God in Western Christianity, 1-19. Cambridge: Cambridge University Press.

\section{Geurts, Kathryn Linn}

2003 Culture and the Senses: Bodily Ways of Knowing in an African Community. (Vol. 3) Berkeley: University of California Press.

\section{Hallowell, A. Irving}

1955 The Self in Its Behavioral Environment. - Culture and Experience, 75-110. Philadelphia: University of Pennsylvania Press.

\section{Hammersley, Martyn \& Paul Atkinson}

2007 Ethnography: Principles in Practice. London: Routledge.

\section{Harding, Susan}

2000 The Book of Jerry Falwell: Fundamentalist Language and Politics. Princeton, NJ: Princeton University Press. 


\section{Henare, Amiria \& Martin Holbraad \& Sari Wastell (eds)}

2007 Thinking through Things: Theorising Artefacts Ethnographically. London: Routledge.

\section{Holbraad, Martin}

2010 Against the Motion, in 'Ontology is Just Another Word for Culture'. - Critique of Anthropology 30(2), 152-200.

\section{Holbraad, Martin}

2012 Truth in Motion: The Recursive Anthropology of Cuban Divination. Chicago: University of Chicago Press.

\section{Howes, David}

2009 Introduction: The Revolving Sensorium. - Howes, David (ed.), The Sixth Sense Reader, 1-52. Oxford, UK: Berg Publishers.

\section{Hunt, Celia \& Fiona Sampson}

2006 Writing: Self and Reflexivity. Basingstoke: Palgrave Macmillan.

\section{Ingold, Tim}

2000a Ancestry, Generation, Substance, Memory, Land. - The Perception of the Environment: Essays on Livelihood, Dwelling and Skill, 132-52. London: Routledge.

2000b Stop, Look and Listen! Vision, Hearing and Human Movement. - The Perception of the Environment: Essays on Livelihood, Dwelling and Skill, 243-88. London: Routledge.

\section{James, William}

1982[1902] The Varieties of Religious Experience: A Study in Human Nature. New York: Penguin Books.

\section{Kirmayer, Laurence J.}

1993 Healing and the Invention of Metaphor: The Effectiveness of Symbols Revisited - Culture, medicine and psychiatry 17(2), 161-95.

\section{Lakoff, George \& Mark Johnson}

2003[1980] Metaphors We Live by. Chicago: University of Chicago Press.

\section{LaNave, Gregory}

2012 Bonaventure. - Gavrilyuk, Paul \& Sarah Coakley (eds) The Spiritual Senses: Perceiving God in Western Christianity, 159-73. Cambridge: Cambridge University Press.

\section{Lindquist, Galina \& Simon Coleman}

2008 Introduction: Against Belief? - Social Analysis 52(1), 1-18.

\section{Lootens, Matthew}

2012 Augustine. - Gavrilyuk, Paul \& Sarah Coakley (eds) The Spiritual Senses: Perceiving God in Western Christianity, 56-70. Cambridge: Cambridge University Press. 


\section{Luhrmann, Tanya}

2012 When God Talks Back: Understanding the American Evangelical Relationship with God. New York: Vintage.

\section{McInroy, Mark}

2012 Origen of Alexandria. - Gavrilyuk, Paul \& Sarah Coakley (eds) The Spiritual Senses: Perceiving God in Western Christianity, 20-35. Cambridge: Cambridge University Press.

Mealey, Mark

2012 John Wesley. - Gavrilyuk, Paul \& Sarah Coakley (eds) The Spiritual Senses: Perceiving God in Western Christianity, 241-56. Cambridge: Cambridge University Press.

\section{Merleau-Ponty, Maurice}

1962 Phenomenology of Perception (Colin Smith, trans.). London: Routledge and Kegan Paul.

\section{Meyer, Birgit}

2010 Aesthetics of Persuasion: Global Christianity and Pentecostalism's Sensational Forms. - South Atlantic Quarterly 109(4), 741-63.

\section{Mitchell, Jon}

2015 Ontology, Mimesis and Divine Intervention: Understanding Catholic Visionaries. - Bull, Michael \& Jon Mitchell (eds), Ritual, Performance and the Senses, 11-30. London: Bloomsbury Publishing.

\section{Needham, Rodney}

1972 Belief, Language, and Experience. Oxford: Blackwell.

\section{Okely, Judith \& Helen Callaway}

1992 Anthropology and Autobiography. London: Routledge.

\section{Porcello, Thomas}

2010 The Reorganization of the Sensory World. - Annual Review of Anthropology 39, 51-66.

\section{Pouillon, Jean}

1982[1979] Remarks on the Verb 'To Believe'. - Izard, Michel \& Pierre Smith (eds), Between Belief and Transgression: Structuralist Essays in Religion, History, and Myth, 1-8. Chicago: University of Chicago Press.

\section{Shils, Edward}

1975 Center and Periphery: Essays in Macrosociology. Chicago: University of Chicago Press.

\section{Stewart, Charles}

2001 Secularism as an Impediment to Anthropological Research - Social Anthropology 9(3), 325-28. 


\section{Stoller, Paul \& Cheryl Olkes}

1987 In Sorcery's Shadow: A Memoir of Apprenticeship among the Songhay of Niger. Chicago: University of Chicago Press.

\section{Stoller, Paul}

1997 Sensuous Scholarship. Philadelphia: University of Pennsylvania Press.

\section{Stromberg, Peter}

1981 Consensus and Variation in the Interpretation of Religious Symbolism: A Swedish Example. - American Ethnologist 8(3), 544-59.

1993 Language and Self-transformation: A Study of the Christian Conversion Narrative. Cambridge, UK: Cambridge University Press.

\section{Tilley, Christopher}

2004 The Materiality of Stone: Explorations in Landscape Phenomenology. Oxford: Berg.

\section{Turner, Victor}

1985 Experience and Performance: Towards a New Processual Anthropology. - Turner, Victor \& Edith Turner, On the Edge of the Bush: Anthropology as Experience, 205-26. Tucson, AZ: University of Arizona Press.

\section{Turner, Victor \& Edith Turner}

1978 Image and Pilgrimage in Christian Culture: Anthropological Perspectives. New York: Columbia University Press.

\section{Turner, Edith}

1992 Psychology, Metaphor, or Actuality? A Probe into Inupiaq Eskimo Healing. - Anthropology of Consciousness 3(1-2), 1-8.

\section{Vigh, Henrik \& David Sausdal}

2014 From Essence Back to Existence: Anthropology Beyond the Ontological Turn - Anthropological Theory 14(1), 49-73.

\section{Vinge, Louise}

1975 The Five Senses: Studies in a Literary Tradition. Lund: Liber Läromedel.

\section{Viveiros de Castro, Eduardo}

1998 Cosmological Deixis and Amerindian Perspectivism. - Journal of the Royal Anthropological Institute 4, 469-88.

2011 Zeno and the Art of Anthropology: Of Lies, Beliefs, Paradoxes, and Other Truths. - Common Knowledge 17(1), 128-45.

2015 Who is Afraid of the Ontological Wolf? Some Comments on an Ongoing Anthropological Debate. - The Cambridge Journal of Anthropology 33(1), 2-17.

Whorf, Benjamin L.

1956 Language, Thought and Reality: Selected Writings of Benjamin Lee Whorf. J.B. Carroll (ed.). Cambridge, MA: MIT Press. 
